Article

\title{
Improvement of Mechanical and Corrosion Properties of Commercially Pure Titanium Using Alumina PEO Coatings
}

\author{
Viorel Malinovschi ${ }^{1}$, Alexandru Horia Marin ${ }^{2, *}\left(\mathbb{C}\right.$, Catalin Ducu ${ }^{3}$, Sorin Moga ${ }^{3}\left(\mathbb{C}\right.$, Victor Andrei ${ }^{4}$, \\ Elisabeta Coaca ${ }^{2}$, Valentin Craciun ${ }^{5,6}$, Mihail Lungu ${ }^{5}$ and Cristian P. Lungu ${ }^{5}$
}

1 Department of Environmental Engineering and Applied Engineering Sciences, University of Pitesti, 110040 Pitesti, Romania; viorel.malinovschi@gmail.com

2 Institute for Nuclear Research Pitesti, 115400 Mioveni, Romania; elisabetaandrei@yahoo.com

3 Research Centre for Advanced Materials, University of Pitesti, 110040 Pitesti, Romania; catalinducu@yahoo.com (C.D.); sorin.g.moga@gmail.com (S.M.)

4 ELSSA Laboratory SRL, 110109 Pitesti, Romania; andvic12@yahoo.com

5 National Institute for Laser, Plasma and Radiation Physics, 077125 Magurele, Romania;

valentincr5@gmail.com (V.C.); lungumihail1989@yahoo.com (M.L.); cristian.lungu@inflpr.ro (C.P.L.)

6 Extreme Light Infrastructure for Nuclear Physics, 077126 Magurele, Romania

* Correspondence: marin.alexandru.horia@gmail.com

check for

updates

Citation: Malinovschi, V.; Marin

A.H.; Ducu, C.; Moga, S.; Andrei, V.;

Coaca, E.; Craciun, V.; Lungu, M.;

Lungu, C.P. Improvement of

Mechanical and Corrosion Properties

of Commercially Pure Titanium

Using Alumina PEO Coatings.

Coatings 2022, 12, 29. https:/ /

doi.org/10.3390/coatings12010029

Academic Editor: Anatoly Kovalev

Received: 2 December 2021

Accepted: 23 December 2021

Published: 27 December 2021

Publisher's Note: MDPI stays neutral with regard to jurisdictional claims in published maps and institutional affiliations.

Copyright: (C) 2021 by the authors. Licensee MDPI, Basel, Switzerland. This article is an open access article distributed under the terms and conditions of the Creative Commons Attribution (CC BY) license (https:// creativecommons.org/licenses/by/ $4.0 /)$.

\begin{abstract}
In this study, the surface of commercially pure titanium (Cp-Ti) was covered by a $21-95 \mu \mathrm{m}-$ thick aluminum oxide layer using plasma electrolytic oxidation. Coating characterization revealed the formation of nodular and granular $\alpha$ - and $\gamma-\mathrm{Al}_{2} \mathrm{O}_{3}$ phases with minor amounts of $\mathrm{TiAl}_{2} \mathrm{O}_{5}$ and $\mathrm{Na}_{2} \mathrm{Ti}_{4} \mathrm{O}_{9}$ which yielded a maximum 49.0 GPa hardness and $50 \mathrm{~N}$ adhesive critical load. The corrosion resistance behavior in $3.5 \mathrm{wt} . \% \mathrm{NaCl}$ solution of all plasma electrolytic oxidation (PEO) coatings was found to be two orders of magnitude higher compared to bare Ti substrate.
\end{abstract}

Keywords: aluminum oxide; $\mathrm{Cp}$-Ti; $\mathrm{PEO}$; corrosion resistance; hardness/adhesion; microstructure

\section{Introduction}

Although titanium and its alloys have been extensively used in industry for a wide variety of applications (e.g., aerospace [1,2], automotive [1], medical [1], marine [2], chemical [3] and petrochemical [3] fields) due to their high strength [1], low density [3], corrosion resistance [1] and biological compatibility [3], research efforts have been devoted to enhancing the mechanical and corrosion-resistance properties of pure titanium and titanium alloys through various processing methods, including physical vapor deposition [4], plasma spraying [5], chemical vapor deposition [6], nitriding [7], laser surface engineering [8-10], atomic layer deposition [11] and plasma electrolytic oxidation (PEO) [12,13]. PEO involves the electrochemical oxidation of a metal substrate (usually $\mathrm{Ti}, \mathrm{Zr}, \mathrm{Al}$ or $\mathrm{Mg}$ ) in an aqueous electrolyte in order to generate oxide coatings with improved wear and corrosion-resistance performance [14]. In this regard, aluminum and aluminum-titanium oxide layers have been successfully prepared on pure $\mathrm{Ti}$ when surface hardening and corrosion protection was required $[15,16]$. Similarly, another approach is to develop and maximize $\alpha-\mathrm{Al}_{2} \mathrm{O}_{3}$ within the coatings with the aim of enhancing mechanical and corrosion properties of various alloys [17-20]. Ghafaripoor [17] reported that an increase of corrosion and tribocorrosion resistance occurred after $\mathrm{PEO}$ processing the $\mathrm{Al}$ alloy substrate in an electrolyte containing $\alpha-\mathrm{Al}_{2} \mathrm{O}_{3}$ particles. At the same time, plasma electrolysis of carbon steel with added $\alpha-\mathrm{Al}_{2} \mathrm{O}_{3}$ in the electrolytic bath generated coatings with improved corrosion behavior [19]. Additionally, $\alpha-\mathrm{Al}_{2} \mathrm{O}_{3}$-based coatings on carbon steel substrate prepared by plasma electrolytic oxidation increased the protection against wear and corrosion conditions [20].

Therefore, the scope of this paper is to enhance the hardness and corrosion properties of $\mathrm{Cp}$-Ti samples by increasing the $\alpha-\mathrm{Al}_{2} \mathrm{O}_{3}$ content in the PEO layers starting from the 
electrolyte composition and concentration. The novelty of the present approach is the strong influence of the electrolytic solution composition on the surface coatings with $\alpha-\mathrm{Al}_{2} \mathrm{O}_{3}$ development on pure $\mathrm{Ti}$ when only sodium aluminate was employed in the PEO process, as opposed to using a mixture of sodium aluminate and sodium hydroxide solution, which led to a dominant aluminum titanate structure with lower mechanical and corrosion resistance properties of the coatings [15].

\section{Materials and Methods}

\subsection{Coating Production}

A detailed description of the oxidation process of grade $2 \mathrm{Cp}$-Ti substrates employing a unipolar, pulsed, direct-current power source at a frequency of $150 \mathrm{~Hz}$ was reported in our previous paper [15]. In this work, the electrolytic bath contained only $\mathrm{NaAlO}_{2}$ at similar concentrations of $10 \mathrm{~g} / \mathrm{L}$ (E1), $15 \mathrm{~g} / \mathrm{L}$ (E2) and $20 \mathrm{~g} / \mathrm{L}$ (E3), without additional NaOH. The new $\mathrm{pH}$ values were found to be $12.3,12.8$ and 13.0, those of electrical conductivity were $11.5,18.0$ and $22.5 \mathrm{mS} / \mathrm{cm}$, respectively. During the galvanostatic mode of operation, the current density and duty cycle were fixed at $0.36 \mathrm{~A} / \mathrm{cm}^{2}$ and $32 \%$, respectively. The actual value of electric voltage was increased slowly to 210, 200 and $190 \mathrm{~V}$ when spark discharges occurred in E1, E2 and E3 electrolyte, respectively, after which the electric current intensity was set and maintained at $2 \mathrm{~A}$ throughout the duration of the experiment. Three oxidation times of 10, 20 and 30 min were applied to the PEO process. The electrolyte temperature was kept at $20^{\circ} \mathrm{C}$.

\subsection{Coating Characterization}

The surface composition of the PEO films was determined with an Escalab 250Xi electron spectrometer (Thermo Scientific, Leicestershire, UK) using monochromatic $\mathrm{AlK}_{\alpha}$ radiation at $1486.6 \mathrm{eV}$. A base pressure of $10^{-8} \mathrm{~Pa}$ was maintained in the ultra-high vacuum chamber during the X-ray photoelectron spectroscopy (XPS) measurements. The acquired binding energies were referenced to the $\mathrm{C} 1$ s line at $284.8 \mathrm{eV}$ of the surface adventitious carbon.

The phase composition of the layers was investigated with a Rigaku Ultima IV X-ray diffractometer (Rigaku, Tokyo, Japan) in a $\theta-\theta$ configuration using a CuK $\alpha(\lambda=1.54 \AA)$ source. The X-ray diffraction (XRD) patterns were scanned in the $2 \theta$ range of $15^{\circ}-80^{\circ}$ with $0.05^{\circ}$ step size and $1^{\circ} / \mathrm{min}$ scan speed. In order to evaluate the concentration ratio of $\alpha-\mathrm{Al}_{2} \mathrm{O}_{3}$ and $\gamma-\mathrm{Al}_{2} \mathrm{O}_{3}$ polycrystalline phases in the PEO layers, high-resolution diffraction patterns were recorded in the $42.6^{\circ}-46.8^{\circ} 2 \theta$ range using a $0.02^{\circ}$ step size and a $0.5^{\circ} / \mathrm{min}$ scan speed.

Qualitative phase analysis of the X-ray diffraction patterns was performed using PDXL: integrated $X$-ray powder diffraction software package (Rigaku, Version 2.4) and PDF-4+ (ICDD, 2020) database. Therefore, $\alpha-\mathrm{Al}_{2} \mathrm{O}_{3}$ (DB card number 04-013-1687), $\gamma-\mathrm{Al}_{2} \mathrm{O}_{3}$ (DB card number 00-050-0741), titanium aluminum oxide $\left(\mathrm{TiAl}_{2} \mathrm{O}_{5}\right.$ (DB card number 04011-9497)) and sodium titanium oxide $\left(\mathrm{Na}_{2} \mathrm{Ti}_{4} \mathrm{O}_{9}\right.$ (DB card number 04-011-2997)) were the polycrystalline phases formed during $\mathrm{PEO}$ processing of all $\mathrm{Cp}$-Ti samples.

The layers' thicknesses were measured using an Olympus B51M metallurgical microscope (Olympus, Tokyo, Japan) at proper magnitude. The microscope was initially calibrated using a standard objective micrometer of $2 \mu \mathrm{m}$.

Morphological and compositional investigations were based on scanning electron microscopy (SEM) and energy dispersive X-ray (EDS) measurements performed using a field-emission scanning electron microscope (HITACHI SU5000 Schottky, Tokyo, Japan) with a nominal resolution of $1.2 \mathrm{~nm}$, integrating an energy-dispersive X-ray analyzer (Oxford Instruments, Oxford, UK) working at an electron accelerating voltage of $30 \mathrm{kV}$.

The adhesion of the deposited layers to the substrates was analyzed using a scratch tester (Teer ST-30, Teer Coatings Ltd, Hartlebury, UK) equipped with a $200 \mu \mathrm{m}$ radius diamond tip. The applied load was linearly increased from 0-100 $\mathrm{N}$ across the sample surface with a loading rate of $10 \mathrm{~N} / \mathrm{min}$ and a total scratch distance of $10 \mathrm{~mm}$. 
Vickers micro-hardness measurements were performed on a microhardness tester (FM-700 Future-tech Corp, Tokyo, Japan) using a diamond Knoop indenter, under an applied load of $1000 \mathrm{gf}$ and a dwell time of $10 \mathrm{~s}$ (to minimize the creep effect), while mean values were reported.

The polarization curves were acquired with a PARSTAT-2273 electrochemical system (Princeton Applied Research, Ametek, Inc., Berwyn, IL, USA) over a voltage range of -0.3 to $+1.0 \mathrm{~V}$ at $1.0 \mathrm{mV} / \mathrm{s}$ in a conventional three-electrode cell. The corrosion resistance of the samples was tested in $3.5 \mathrm{wt} . \% \mathrm{NaCl}$ solution at room temperature.

\section{Results}

\subsection{XPS}

XPS investigations were carried out to assess the bonding state of atoms at the surface. The chemical interaction between the metal substrate and $\mathrm{NaAlO}_{2}$ electrolyte solution, as well as the effects of plasma oxidation on $\mathrm{Ti}$, were addressed by acquiring the highresolution spectra of the detected elements.

Therefore, Figure 1a-c shows the superimposed spectra of A12p, Ti2p and Na1s for the three sample groups, indicating a similar chemical behavior. As seen below, the chemical environment of the constituent elements was unchanged during the PEO treatment.

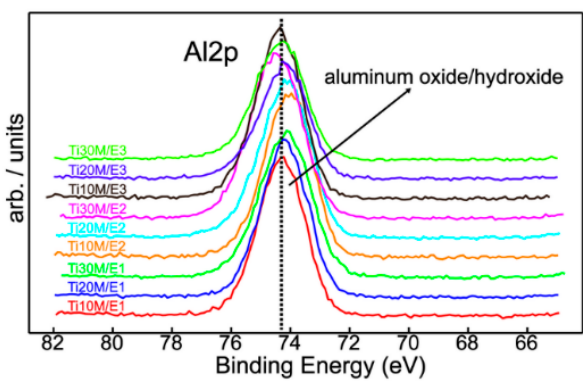

(a)

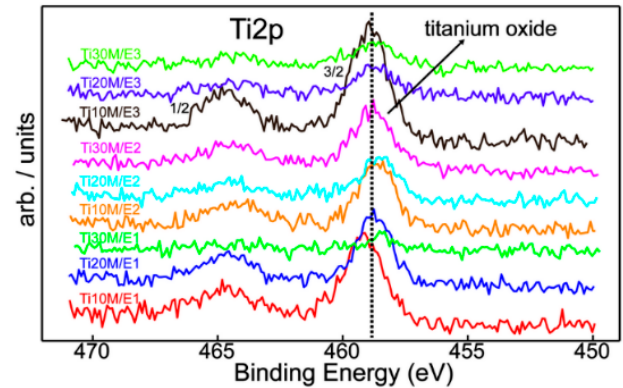

(b)

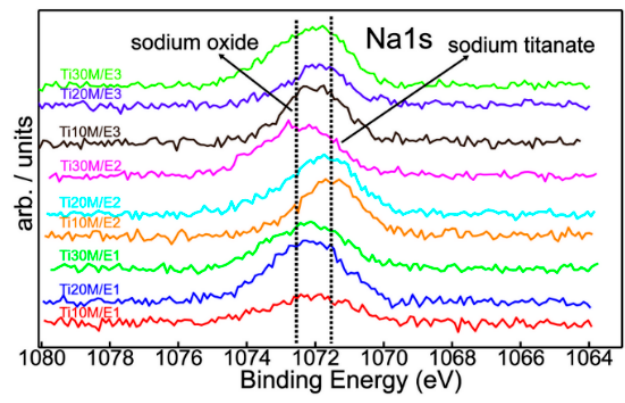

(c)

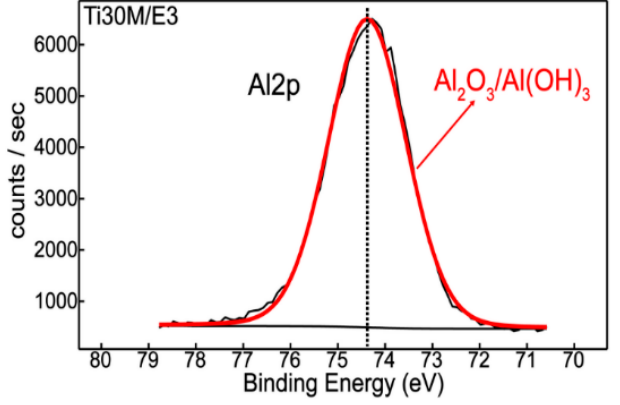

(d)

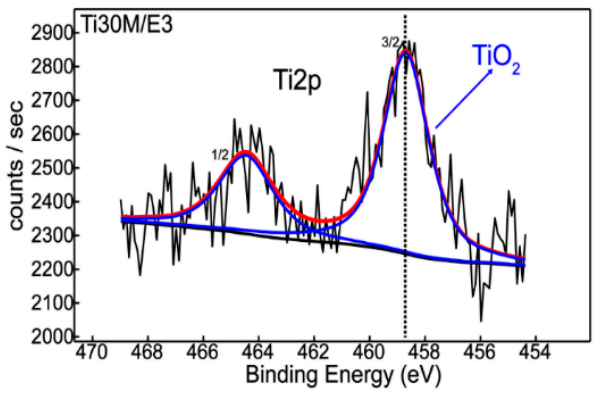

(e)

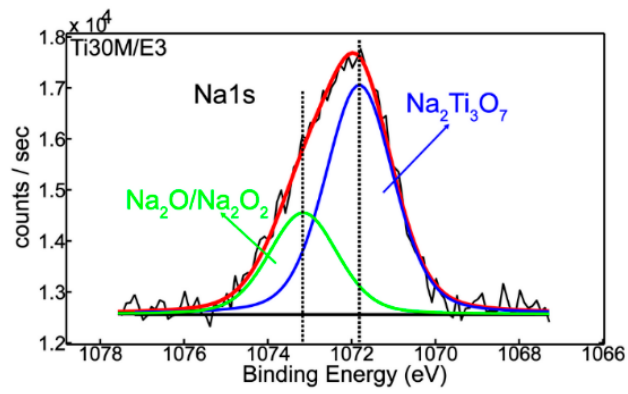

(f)

Figure 1. XPS spectra of the three sets of samples: (a) Al2p; (b) Ti2p; (c) Na1s. Peak-fitted XPS spectra of the third set of samples prepared in E3 electrolyte: (d) Al2p; (e) Ti2p; (f) Na1s. 
After curve-fitting the Al2p core-level (Figure 1d), the peak at $74.3 \pm 0.2 \mathrm{eV}$ was assigned to $\mathrm{Al}_{2} \mathrm{O}_{3} / \mathrm{Al}(\mathrm{OH})_{3}$ [21,22], which was grown on the surface of Ti samples. This is in excellent agreement with the bulk $\alpha-\mathrm{Al}_{2} \mathrm{O}_{3}$ and $\gamma-\mathrm{Al}_{2} \mathrm{O}_{3}$ composition determined by XRD analysis, discussed and illustrated in the next section. Quantitatively, each oxidation step led to an enrichment of aluminum at the surface (Table 1). Further, the Ti2p photoelectron line (Figure 1e) at $458.7 \pm 0.2 \mathrm{eV}$ can be attributed to $\mathrm{Ti}^{4+}$ in $\mathrm{TiO}_{2}$ [21-23]. It is important to note that the low amount of $\mathrm{Ti}$ (Table 1) found oxidized at the surface suggests the formation of an alumina coating layer on top of the substrate surface. The Na1s corelevel peak (Figure 1f) was fitted with two components located at $1071.8 \pm 0.2 \mathrm{eV}$ and $1073.0 \pm 0.2 \mathrm{eV}$ corresponding to $\mathrm{Na}_{2} \mathrm{Ti}_{3} \mathrm{O}_{7}$ [24] and $\mathrm{Na}_{2} \mathrm{O} / \mathrm{Na}_{2} \mathrm{O}_{2}$ [21,25], respectively. In the absence of $\mathrm{NaOH}$ addition to the electrolytic solution, the oxidation process was different, as it maximized the appearance of aluminum and titanium oxides to the detriment of titanium aluminate, both on the surface and in the bulk of the PEO samples, in contrast to our previous study [15]. Therefore, the relevant changes in the PEO coatings produced only with sodium aluminate electrolyte showed an enhancement of aluminum oxide on pure Ti samples.

Table 1. Element relative concentrations (at.\%).

\begin{tabular}{ccccc}
\hline Sample & O1s & Na1s & A12p & Ti2p \\
\hline Ti10M/E1 & 74.1 & 2.3 & 22.3 & 1.3 \\
Ti20M/E1 & 71.5 & 5.1 & 22.4 & 1.0 \\
Ti30M/E1 & 71.5 & 4.1 & 24.1 & 0.3 \\
Ti10M/E2 & 73.5 & 3.8 & 21.9 & 0.8 \\
Ti20M/E2 & 71.4 & 4.3 & 23.7 & 0.6 \\
Ti30M/E2 & 69.0 & 3.9 & 26.2 & 0.9 \\
Ti10M/E3 & 72.3 & 3.2 & 23.2 & 1.3 \\
Ti20M/E3 & 75.0 & 3.5 & 21.0 & 0.5 \\
Ti30M/E3 & 71.5 & 5.4 & 22.5 & 0.6 \\
\hline
\end{tabular}

\subsection{XRD Analysis}

Figure 2a-c shows the XRD patterns of the PEO coatings obtained in E1, E2 and E3 electrolyte solutions.

The main phases present in the coatings were similar for the same duration of the PEO process, regardless of the electrolyte concentration involved. Consequently, aluminum oxide and aluminum titanate were the principal phases for a process time of $10 \mathrm{~min}$ while aluminum oxide dominated the growing oxide layer when a $30 \mathrm{~min}$ interval was applied.

Additionally, for any concentration of sodium aluminate in the electrolyte, aluminum titanate decreased with increasing aluminum oxide as a result of increased oxidation time. A comparison of the XRD lines of $\alpha-\mathrm{Al}_{2} \mathrm{O}_{3}\left(2 \theta=25.6^{\circ} ; 62.4 \%\right)$ and $\mathrm{TiAl}_{2} \mathrm{O}_{5}\left(2 \theta=26.4^{\circ} ; 100 \%\right)$ phases indicates there was a significant increase in the intensity of $\alpha-\mathrm{Al}_{2} \mathrm{O}_{3}$ accompanied by a decrease of $\mathrm{TiAl}_{2} \mathrm{O}_{5}$, when an increased PEO process time was applied for samples prepared under E1, E2 and E3 electrolytes, respectively. Mass concentrations of the phases identified in the coating layers were estimated with PDXL Rietveld analysis package for pattern decomposition using the Pawley method [26]. Thus, the concentration of aluminum titanate decreased from $\sim 65 \%$ to $\sim 5 \%$ while the content of aluminum oxide increased from $\sim 40 \%$ to $90 \%$ for 10 and 30 min treatment times, respectively, under E1 electrolyte solution. In the case of the E3 electrolyte, the amount of aluminum titanate decreased from $\sim 24 \%$ to $\sim 5 \%$, accompanied by an increase of aluminum oxide from $\sim 70 \%$ to $\sim 93 \%$, after 10 and $30 \mathrm{~min}$ process times, respectively.

In order to evaluate the variation of phase concentrations within the PEO coatings, the calculated ratio of $\alpha-\mathrm{Al}_{2} \mathrm{O}_{3}$ and $\gamma-\mathrm{Al}_{2} \mathrm{O}_{3}$ relative concentrations $\left(\mathrm{C}_{\alpha} / \mathrm{C}_{\gamma}\right)$ was performed using Equation (1) [27]:

$$
\mathrm{I}_{\alpha} / \mathrm{I}_{\gamma}=\left(\mathrm{A}_{\alpha} / \mathrm{A}_{\gamma}\right)\left(\mathrm{C}_{\alpha} / \mathrm{C}_{\gamma}\right)
$$


where, $I_{\alpha}$ and $I_{\gamma}$ represent the integral intensities of $(113)_{\alpha}$ and $(004)_{\gamma}$ diffraction lines calculated from the high-resolution diffraction patterns. $\mathrm{A}_{\alpha}$ and $\mathrm{A}_{\gamma}$ are the integral theoretical intensities of $(113)_{\alpha}$ and (004) $\gamma$ diffraction lines.

Figure $2 \mathrm{~d}-\mathrm{f}$ displays the high-resolution diffractograms acquired in the angular range of $42.6^{\circ}-46.8^{\circ}$ from which the integral intensity ratio $\left(\mathrm{I}_{\alpha} / \mathrm{I}_{\gamma}\right)$ of $100 \%$ intensity diffraction peaks was estimated according to (113) and (004) for $\alpha-\mathrm{Al}_{2} \mathrm{O}_{3}\left(2 \theta=43.35^{\circ}\right)$ and $\gamma-\mathrm{Al}_{2} \mathrm{O}_{3}$ $\left(2 \theta=45.66^{\circ}\right)$ phases, respectively.

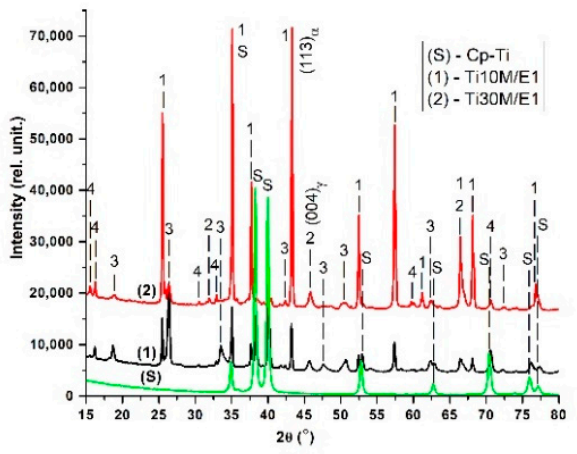

(a)

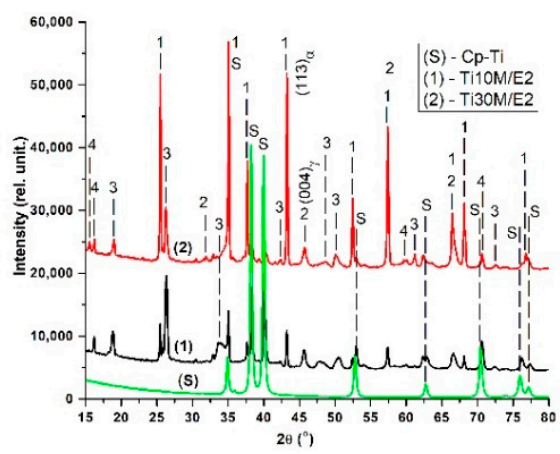

(c)

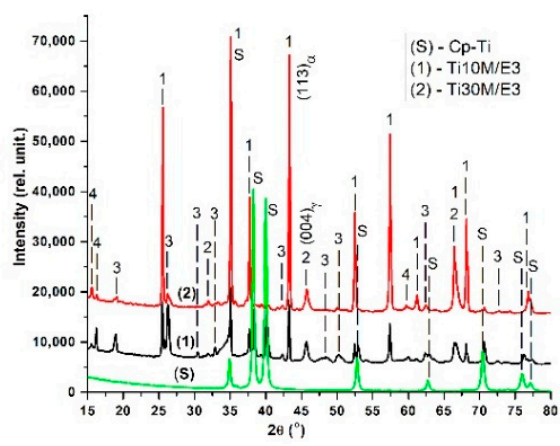

(e)

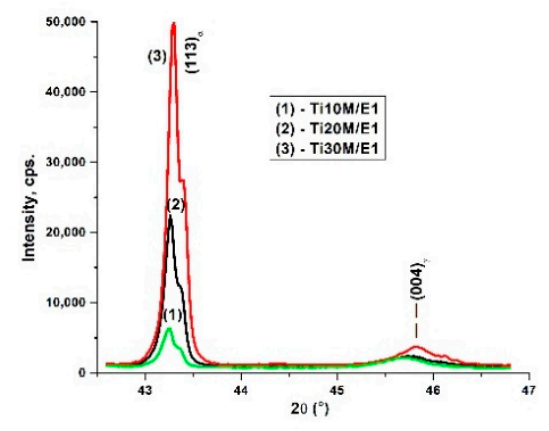

(b)

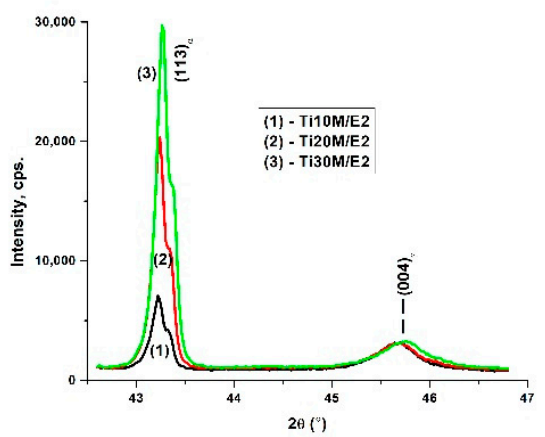

(d)

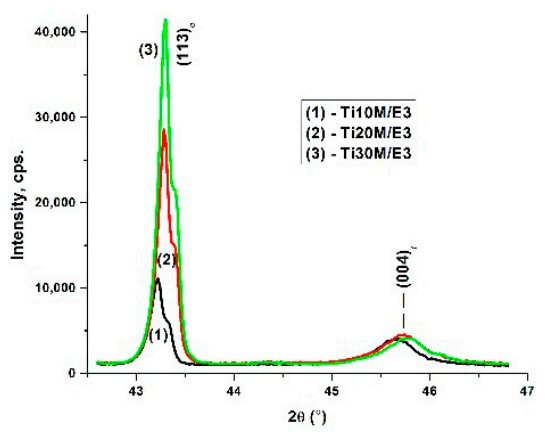

(f)

Figure 2. X-ray diffraction patterns of the PEO coatings formed after 10 and 30 min process time in: (a) E1; (b) E2; (c) E3 electrolytes. High-resolution diffraction patterns of the PEO coatings formed after 10, 20 and 30 min process time in: (d) E1; (e) E2; (f) E3 electrolytes. $1: \alpha-\mathrm{Al}_{2} \mathrm{O}_{3}$ (DB card number 04-013-1687); 2: $\gamma-\mathrm{Al}_{2} \mathrm{O}_{3}$ (DB card number 00-050-0741); 3: $\mathrm{TiAl}_{2} \mathrm{O}_{5}$ (DB card number 04-011-9497); 4: $\mathrm{Na}_{2} \mathrm{Ti}_{4} \mathrm{O}_{9}$ (DB card number 04-011-2997); S: Cp-Ti grade 2 (DB card number 04-007-9313).

The calculated value of the $C_{\alpha} / C_{\gamma}$ ratio from Equation (1) increased significantly, from $\sim 1$ to $\sim 6$ for samples treated for 10 and $30 \mathrm{~min}$, respectively. It was found that for the 
same period of the PEO process, there were no significant differences in the intensity ratios under increasing electrolyte concentration. Thus, the ratio values obtained at 10, 20 and 30 min electrolytic oxidation were in the ranges of $0.9-1.4,3.4-4.4$ and 5-6.5, respectively.

Qualitative phase analysis of the diffraction patterns of the PEO layers deposited on $\mathrm{Cp}$-Ti substrates in electrolytes containing the same amount of sodium aluminate (10, 15 and $20 \mathrm{~g} / \mathrm{L}$ ) but with $2 \mathrm{~g} / \mathrm{L}$ of $\mathrm{NaOH}$ (as performed in [15]) highlighted the existence of aluminum titanate as a dominant phase for all samples. In these layers, a depleted content of aluminum oxide was found. The experimental conditions under which the PEO treatment was performed corresponded to those used for processing the samples analyzed in this study.

The presence of aluminum oxide as a major component in the coatings prepared in E1, E2 and E3 electrolytes could be explained by the low electrical conductivity of these solutions $(11.5,18.0,22.5 \mathrm{mS} / \mathrm{cm})$ compared to the values obtained from the same electrolytes when $2 \mathrm{~g} / \mathrm{L} \mathrm{NaOH}$ was added $(22.4,26.0,29.8 \mathrm{mS} / \mathrm{cm}$ ) in our previous work [15]. This is why for an identical current density of $0.36 \mathrm{~A} / \mathrm{cm}^{2}$, the actual values of the working voltages applied on the samples during the process were considerably higher for the above electrolytes (E1, E2 and E3). Thus, we observed a variation of the effective voltage from 220 to $270 \mathrm{~V}$ when a $\mathrm{NaOH}$-based electrolyte was employed [15]. In contrast, the actual voltage changed from 240 to $330 \mathrm{~V}$ in the absence of $\mathrm{NaOH}$ in the electrolytic bath. Because of this, in the outer layer, the higher working voltages reached during the PEO experiment produced a considerable temperature increase in the microarc electric discharge region, favoring the partial decomposition of $\mathrm{TiAl}_{2} \mathrm{O}_{5}$ (which is metastable) to $\mathrm{TiO}_{2}$ and $\mathrm{Al}_{2} \mathrm{O}_{3}$ [28]. At the same time, aluminum oxide was subjected to phase transformation, leading to the formation of $\alpha$ - and $\gamma-\mathrm{Al}_{2} \mathrm{O}_{3}$ phases, while $\mathrm{TiO}_{2}$ combined with $\mathrm{Na}_{2} \mathrm{O}$ to form $\mathrm{Na}_{2} \mathrm{Ti}_{4} \mathrm{O}_{9}$ $\left(\mathrm{Na}_{2} \mathrm{O} \cdot 4 \mathrm{TiO}_{2}\right)$.

To confirm this hypothesis, diffraction data were acquired for the PEO films deposited on Ti10M/E1 and Ti30M/E1 samples, after mechanical polishing with sandpaper and removal of an approximately $10 \mu \mathrm{m}$-thick surface layer. Figure 3a,b shows the results of the qualitative phase analysis for the superimposed diffraction patterns of the PEO layers before and after removing a portion of the surface. Therefore, for the Ti10M/E1 sample, we observed an enrichment of aluminum titanate accompanied with a depletion of aluminum oxide (the remaining PEO layer had a thickness of $\sim 10 \mu \mathrm{m}$ ) while an even higher concentration of aluminum titanate was found for the Ti30M/E1 sample. In this case, the remaining PEO layer had a thickness of $\sim 70 \mu \mathrm{m}$.

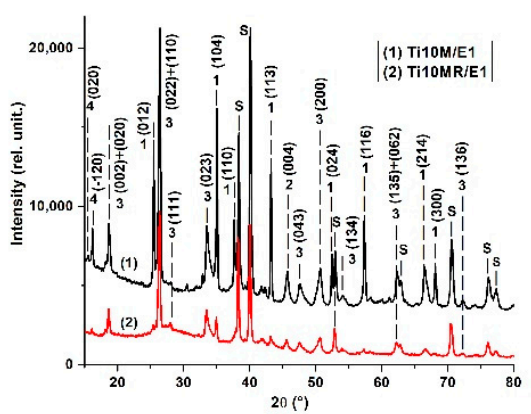

(a)

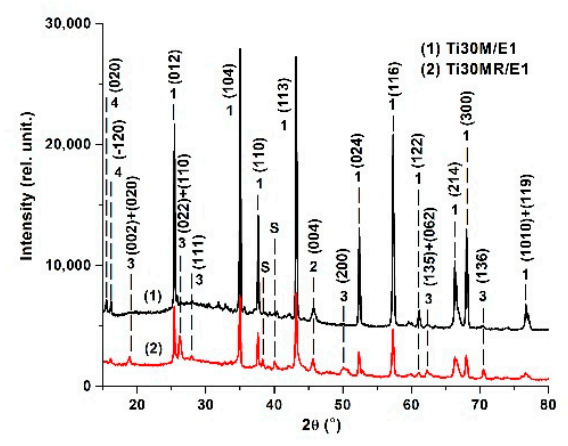

(b)

Figure 3. Qualitative phase analysis of the diffraction patterns of the Ti10M/E1 (a) and Ti30M/E1 (b) samples, before (1) and after (2) removing a $10 \mu$ m-thick surface layer. $1: \alpha-\mathrm{Al}_{2} \mathrm{O}_{3} ; 2: \gamma-\mathrm{Al}_{2} \mathrm{O}_{3} ; 3$ : $\mathrm{TiAl}_{2} \mathrm{O}_{5} ; 4: \mathrm{Na}_{2} \mathrm{Ti}_{4} \mathrm{O}_{9} ; \mathrm{S}$ : Cp-Ti grade 2 .

\subsection{Layer Thickness}

Cross-sectional optical metallography was used to observe and determine the coating layer thickness from an overall view perspective. Therefore, a direct proportionality 
between the film thickness, treatment time and electrolyte concentration was observed, as expected (Figure 4). The thickness of the PEO layers varied from approximately 21.4 to $95.5 \mu \mathrm{m}$ depending on the employed processing conditions. Moreover, it is worth mentioning that the oxide coating thickness was roughly similar for each oxidation step, confirming the uniform growth of the PEO films on Ti substrate (Figure 4, Table 2), in agreement with cross-sectional SEM results.
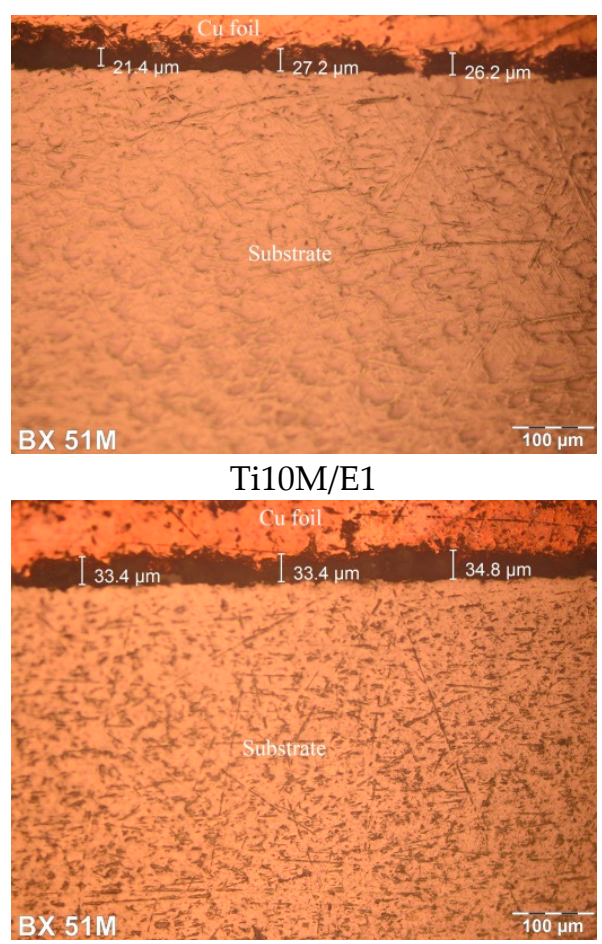

Ti10M/E2

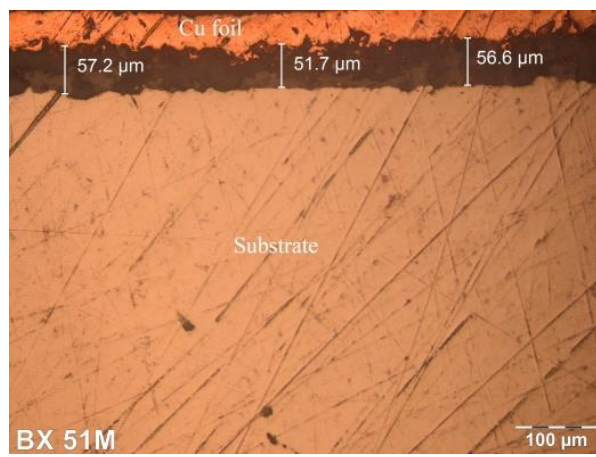

Ti10M/E3

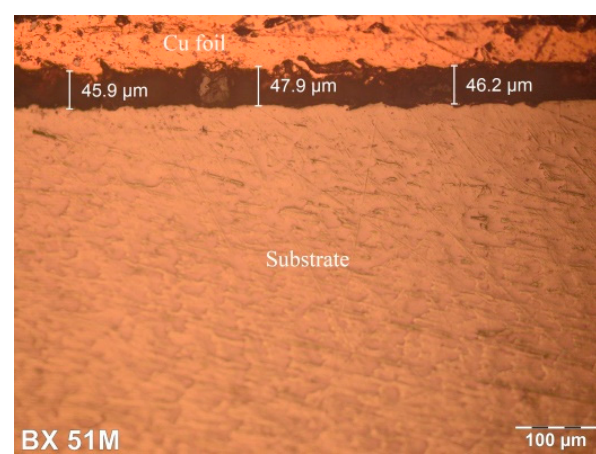

Ti20M/E1

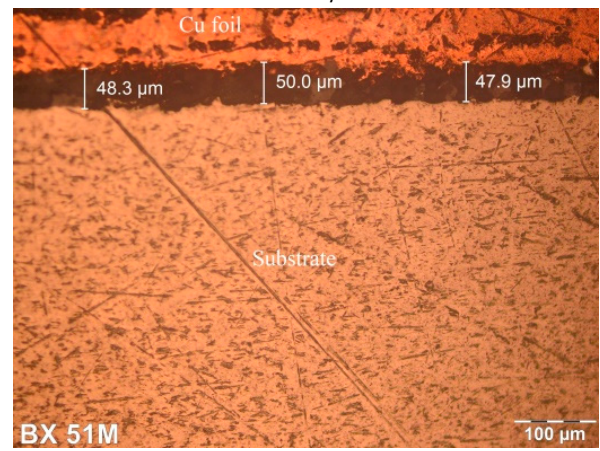

Ti20M/E2

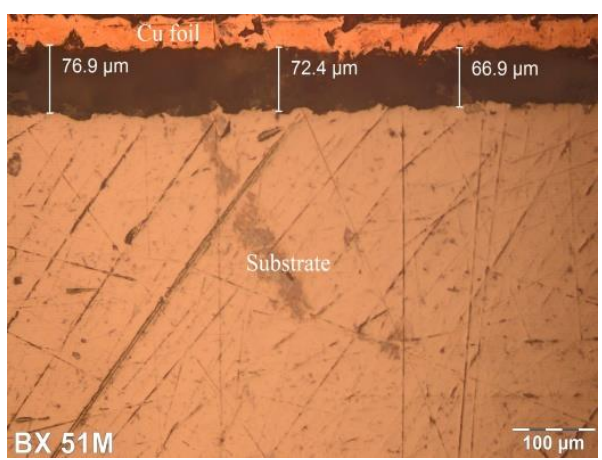

Ti20M/E3

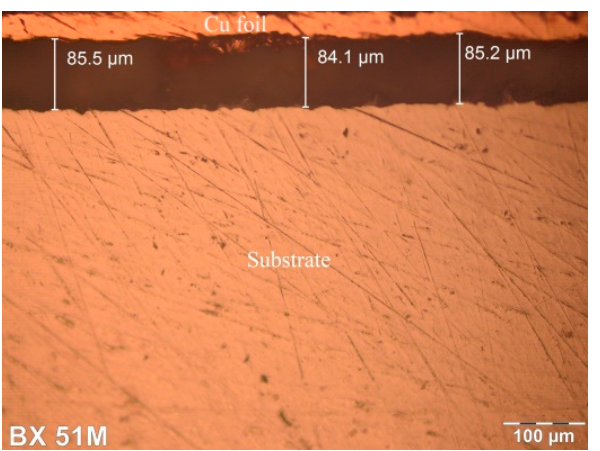

Ti30M/E1

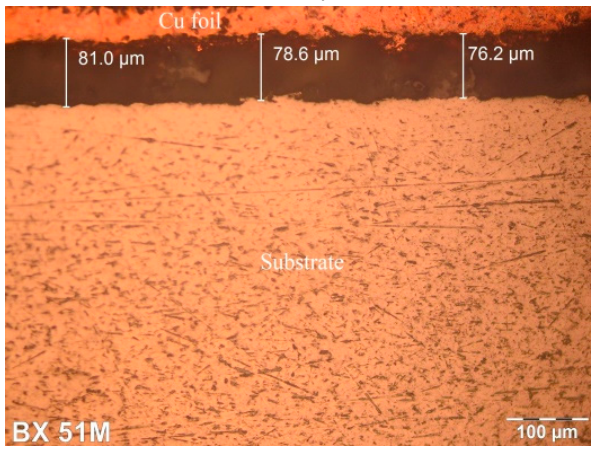

Ti30M/E2

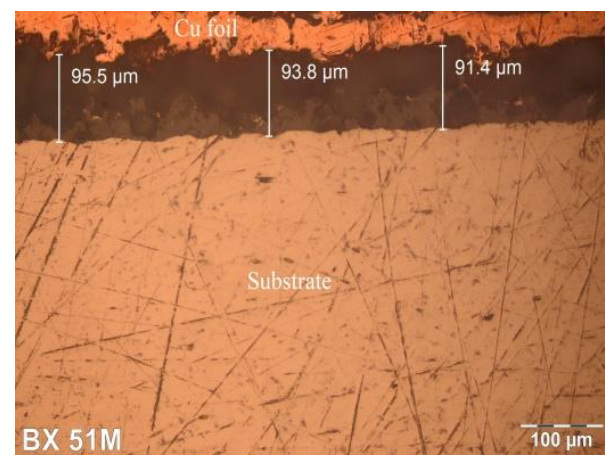

Ti30M/E3

Figure 4. Cross-sectional metallographic images of the PEO layers for the three sets of experiments.

\subsection{SEM/EDS Surface Morphology of the PEO Coatings}

The surface morphology and the chemical composition of the PEO coated samples were investigated by SEM and EDS at different stages of the layer growth process. Figures 5 and 6 shows the SEM micrographs of the films obtained in E1 and E2 electrolytes after 10, 20 and 30 min treatment periods. From the low-magnification images in Figure $5 \mathrm{a}, \mathrm{c}, \mathrm{e}$, it can be clearly seen that by increasing the oxidation time, the nodular structures on the surface increased dramatically, covering the micropores with aluminum oxide nodules, which led to a uniform and dense microstructure of the coating layer. As a consequence, being composed of $\mathrm{Al}_{2} \mathrm{O}_{3}$, the abundance of these nodules on the surface 
reduced the porosity and improved the hardness of the layers (Table 2). No cracks or fractures were visible in the investigated samples.

Table 2. Obtained thickness, microhardness and critical load values for the PEO layers after three sets of experiments.

\begin{tabular}{cccc}
\hline Sample & $\begin{array}{c}\text { Thickness of the } \\
\text { Layers }(\boldsymbol{\mu m})\end{array}$ & HV1000 (GPa) & $\mathbf{L}_{\mathbf{c} 2}(\mathbf{N})$ \\
\hline $\mathrm{Cp}-\mathrm{Ti}$ & - & $180,(1.8)$ & - \\
$\mathrm{Ti} 10 \mathrm{M} / \mathrm{E} 1$ & $21.4-27.2$ & $1600,(15.7)$ & 15 \\
$\mathrm{Ti} 20 \mathrm{M} / \mathrm{E} 1$ & $45.9-47.9$ & $2700,(26.5)$ & 38 \\
$\mathrm{Ti30M} / \mathrm{E} 1$ & $84.1-85.5$ & $4000,(39.2)$ & 42 \\
$\mathrm{Ti10M} / \mathrm{E} 2$ & $33.4-34.8$ & $2500,(24.5)$ & 35 \\
Ti20M/E2 & $47.9-50.0$ & $3500,(34.3)$ & 38 \\
Ti30M/E2 & $76.2-81.0$ & $5000,(49.0)$ & 11 \\
Ti10M/E3 & $51.7-57.2$ & $1500,(14.7)$ & 38 \\
Ti20M/E3 & $66.9-76.9$ & $2000,(19.6)$ & 50 \\
Ti30M/E3 & $91.4-95.5$ & $3800,(37.3)$ &
\end{tabular}

Likewise, high-magnification images (Figure $5 b, d, f)$ showed a densification effect of aluminum oxide around the pores, resulting in a pore density decrease when longer process times were applied. A similar effect of pore reduction in the presence of $\alpha-\mathrm{Al}_{2} \mathrm{O}_{3}$ was reported [18,19]. The pore sizes were up to $20 \mu \mathrm{m}$. EDS analysis was performed in different regions of the samples to determine the chemical composition of the coatings, as shown in Figure $5 b, d, f$. As already stated, the highest concentration of aluminum and oxygen was in the region near the pore walls corresponding to the nodule structures. The pores and their walls contained larger amounts of titanium, coming from the substrate through the pore holes.

As expected, the tendency of aluminum oxide to conglomerate on the surface was also found when the aluminate electrolyte concentration was increased. However, the shape of $\mathrm{Al}_{2} \mathrm{O}_{3}$ surface formations changed from nodular to grain-like structures (Figure $\left.7 \mathrm{~b}, \mathrm{~d}, \mathrm{f}\right)$.

In terms of mechanical characteristics, the surface morphology could be associated with variations in hardness and adhesion strength values, possibly caused by changes in the microstructure from nodules to grains. In this regard, the results presented in Table 2 indicate a slight decrease of microhardness values as well as an increase of scratch resistance after an increased electrolyte concentration. On the other hand, the corrosion resistance was clearly improved after PEO oxidation, regardless of the morphology of the coatings (Table 3).

Table 3. Results of potentiodynamic polarization tests in $3.5 \mathrm{wt} . \% \mathrm{NaCl}$ solution at room temperature.

\begin{tabular}{|c|c|c|c|}
\hline Sample & $E_{\text {corr }}(m V)$ & $\mathrm{i}_{\text {corr }}\left(\mathrm{A} / \mathrm{cm}^{2}\right)$ & $\mathrm{V}_{\text {corr }}(\mathrm{mmpy})$ \\
\hline $\mathrm{Cp}-\mathrm{Ti}$ & -518 & $0.8 \times 10^{-6}$ & $102.4 \times 10^{-4}$ \\
\hline Ti10M/E1 & -142 & $4.5 \times 10^{-8}$ & $10.0 \times 10^{-4}$ \\
\hline $\mathrm{Ti20M} / \mathrm{E} 1$ & -8.5 & $1.0 \times 10^{-8}$ & $4.5 \times 10^{-4}$ \\
\hline Ti30M/E1 & 134 & $0.3 \times 10^{-8}$ & $1.8 \times 10^{-4}$ \\
\hline Ti10M/E2 & -247 & $3.0 \times 10^{-8}$ & $8.8 \times 10^{-4}$ \\
\hline Ti20M/E2 & 193 & $1.0 \times 10^{-8}$ & $3.5 \times 10^{-4}$ \\
\hline Ti30M/E2 & 225 & $0.2 \times 10^{-8}$ & $1.0 \times 10^{-4}$ \\
\hline Ti10M/E3 & -253 & $2.0 \times 10^{-8}$ & $5.9 \times 10^{-4}$ \\
\hline Ti20M/E3 & 155 & $0.8 \times 10^{-8}$ & $2.6 \times 10^{-4}$ \\
\hline $\mathrm{Ti} 30 \mathrm{M} / \mathrm{E} 3$ & 314 & $0.1 \times 10^{-8}$ & $0.6 \times 10^{-4}$ \\
\hline
\end{tabular}




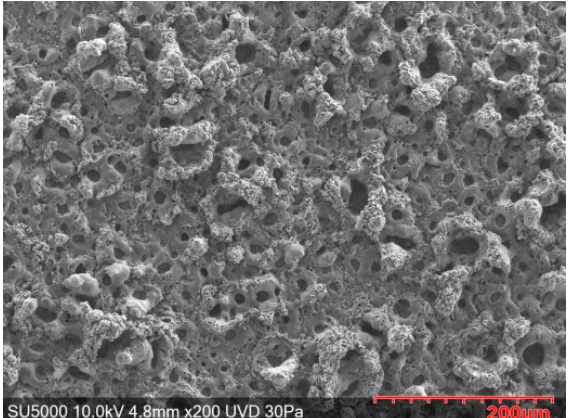

(a) Ti10M/E1

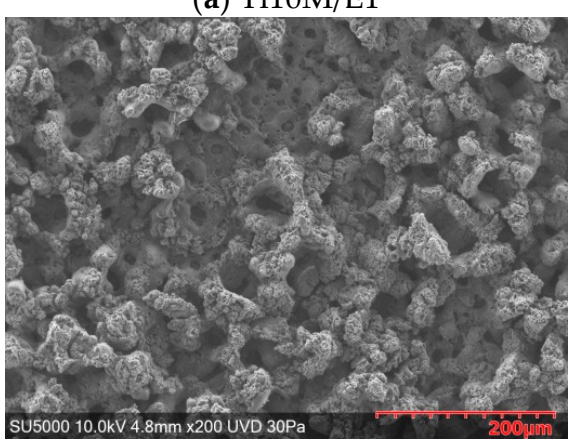

(c) Ti20M/E1

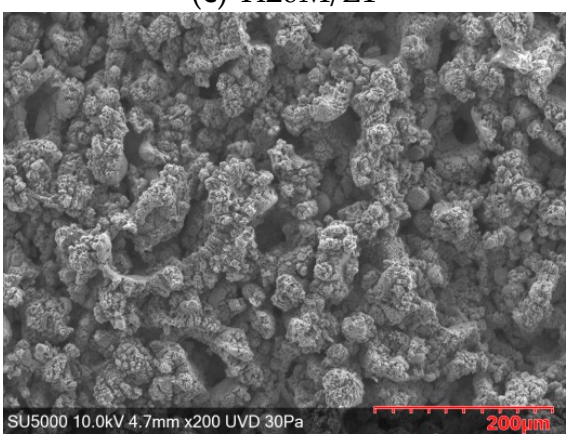

(e) Ti30M/E1

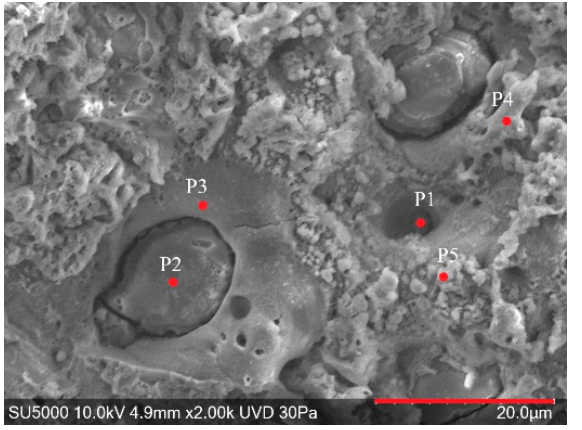

\begin{tabular}{ccccc}
\hline $\begin{array}{c}\text { Point scan } \\
\text { no. }\end{array}$ & $\begin{array}{c}\mathrm{Ti} \\
(\text { wt.\%) }\end{array}$ & $\begin{array}{c}\mathrm{Al} \\
(\text { wt.\%) }\end{array}$ & $\begin{array}{c}\mathrm{O} \\
(\text { wt.\%) }\end{array}$ & $\begin{array}{c}\mathrm{Na} \\
(\text { wt.\%) }\end{array}$ \\
\hline 1 & 39.7 & 19.5 & 40.4 & 0.4 \\
2 & 8.2 & 31.7 & 59.7 & 0.4 \\
3 & 31.5 & 28.0 & 40.2 & 0.3 \\
4 & 4.3 & 39.7 & 53.6 & 2.4 \\
5 & 17.4 & 35.0 & 46.6 & 1.0
\end{tabular}

(b) Ti10M/E1

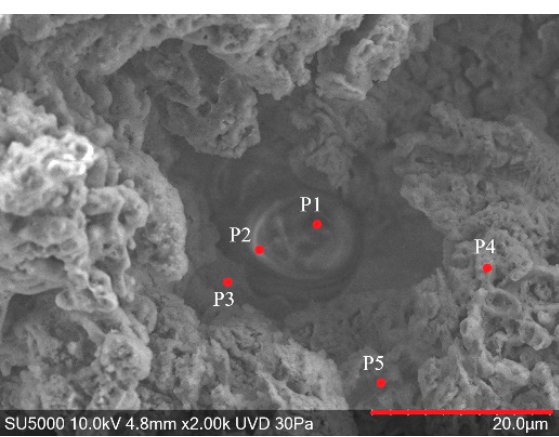

\begin{tabular}{ccccc}
\hline $\begin{array}{c}\text { Point scan } \\
\text { no. }\end{array}$ & $\begin{array}{c}\mathrm{Ti} \\
\text { (wt.\%) }\end{array}$ & $\begin{array}{c}\mathrm{Al} \\
\text { (wt.\%) }\end{array}$ & $\begin{array}{c}\mathrm{O} \\
\text { (wt.\%) }\end{array}$ & $\begin{array}{c}\mathrm{Na} \\
\text { (wt.\%) }\end{array}$ \\
\hline 1 & 9.2 & 39.4 & 50.1 & 1.3 \\
2 & 7.1 & 41.8 & 49.8 & 1.3 \\
3 & 29.9 & 24.6 & 44.7 & 0.8 \\
4 & 0.5 & 45.8 & 53.2 & 0.5 \\
5 & 2.5 & 46.9 & 49.1 & 1.5
\end{tabular}

(d) Ti20M/E1

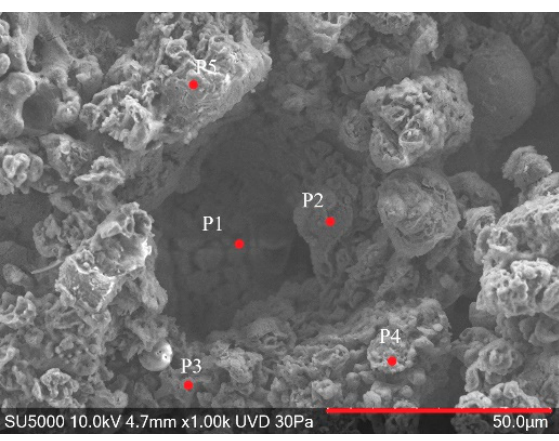

\begin{tabular}{ccccc}
\hline $\begin{array}{c}\text { Point scan } \\
\text { no. }\end{array}$ & $\begin{array}{c}\mathrm{Ti} \\
\text { (wt.\%) }\end{array}$ & $\begin{array}{c}\mathrm{Al} \\
(\text { wt.\%) }\end{array}$ & $\begin{array}{c}\mathrm{O} \\
\text { (wt.\%) }\end{array}$ & $\begin{array}{c}\mathrm{Na} \\
\text { (wt.\%) }\end{array}$ \\
\hline 1 & 7.2 & 41.1 & 50.5 & 1.2 \\
2 & 4.8 & 42.9 & 51.2 & 1.1 \\
3 & 0.2 & 45.8 & 53.3 & 0.7 \\
4 & 0.7 & 49.4 & 48.3 & 1.6 \\
5 & 1.2 & 47.5 & 50.2 & 1.1
\end{tabular}

(f) $\mathrm{Ti} 30 \mathrm{M} / \mathrm{E} 1$

Figure 5. SEM images of the layers grown in E1 electrolyte after 10, 20 and 30 min treatment period: low magnification (a,c,e); high magnification and EDS analysis points $(\mathbf{b}, \mathbf{d}, \mathbf{f})$; point element mass concentrations (wt.\%). 


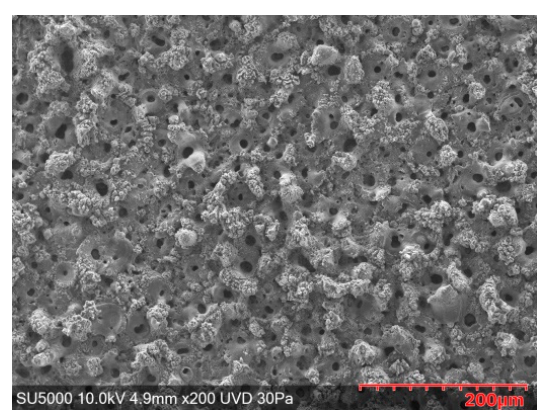

(a) Ti10M/E2

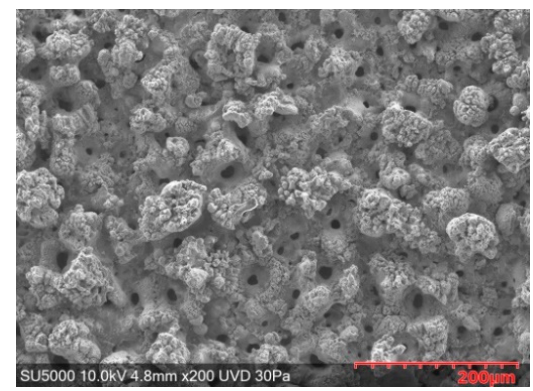

(c) Ti20M/E2

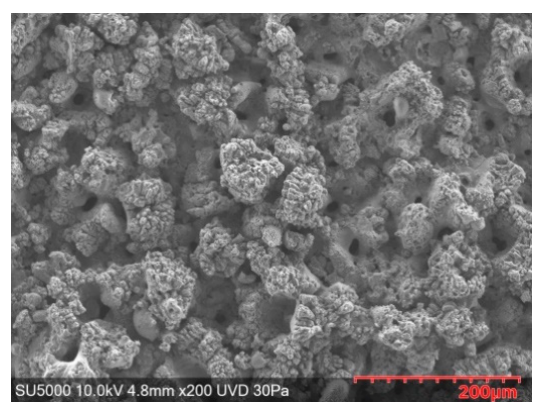

(e) Ti30M/E2
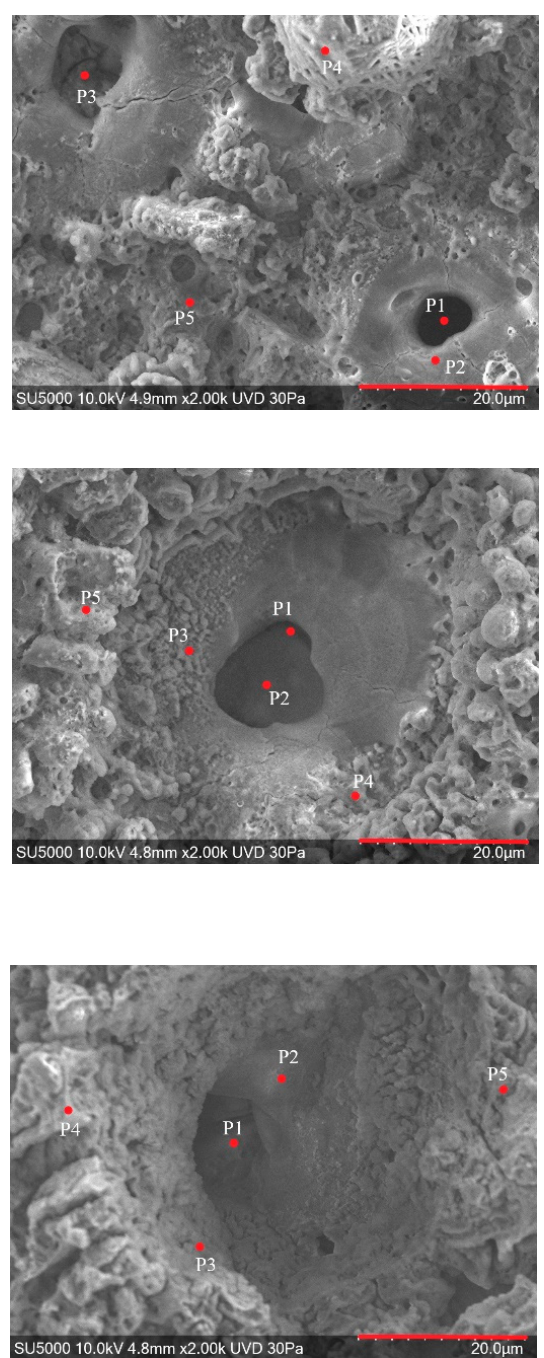

\begin{tabular}{ccccc}
\hline $\begin{array}{c}\text { Point scan } \\
\text { no. }\end{array}$ & $\begin{array}{c}\mathrm{Ti} \\
\text { (wt.\%) }\end{array}$ & $\begin{array}{c}\mathrm{Al} \\
\text { (wt.\%) }\end{array}$ & $\begin{array}{c}\mathrm{O} \\
(\text { wt.\%) }\end{array}$ & $\begin{array}{c}\mathrm{Na} \\
\text { (wt.\%) }\end{array}$ \\
\hline 1 & 53.3 & 12.5 & 33.8 & 0.3 \\
2 & 20.9 & 30.6 & 48.3 & 0.2 \\
3 & 32.8 & 22.1 & 44.4 & 0.6 \\
4 & 4.9 & 58.9 & 35.7 & 0.5 \\
5 & 27.7 & 32.2 & 39.5 & 0.6
\end{tabular}

(b) Ti10M/E2

\begin{tabular}{ccccc}
\hline $\begin{array}{c}\text { Point scan } \\
\text { no. }\end{array}$ & $\begin{array}{c}\mathrm{Ti} \\
\text { (wt.\%) }\end{array}$ & $\begin{array}{c}\mathrm{Al} \\
\text { (wt.\%) }\end{array}$ & $\begin{array}{c}\mathrm{O} \\
\text { (wt.\%) }\end{array}$ & $\begin{array}{c}\mathrm{Na} \\
\text { (wt.\%) }\end{array}$ \\
\hline 1 & 12.1 & 36.6 & 50.3 & 1.0 \\
2 & 11.2 & 37.2 & 50.6 & 1.1 \\
3 & 31.0 & 26.2 & 42.2 & 0.6 \\
4 & 16.2 & 34.3 & 48.8 & 0.7 \\
5 & 0.9 & 51.5 & 47.1 & 0.5
\end{tabular}

(d) $\mathrm{Ti} 20 \mathrm{M} / \mathrm{E} 2$

\begin{tabular}{ccccc}
\hline $\begin{array}{c}\text { Point scan } \\
\text { no. }\end{array}$ & $\begin{array}{c}\mathrm{Ti} \\
\text { (wt.\%) }\end{array}$ & $\begin{array}{c}\mathrm{Al} \\
(\text { wt.\%) }\end{array}$ & $\begin{array}{c}\mathrm{O} \\
\text { (wt.\%) }\end{array}$ & $\begin{array}{c}\mathrm{Na} \\
(\text { wt.\%) }\end{array}$ \\
\hline 1 & 6.3 & 42.4 & 50.0 & 1.3 \\
2 & 19.4 & 28.9 & 51.0 & 0.7 \\
3 & 5.3 & 44.6 & 49.3 & 0.9 \\
4 & 1.0 & 49.0 & 48.4 & 1.7 \\
5 & 29.7 & 30.4 & 39.4 & 0.6
\end{tabular}

(f) $\mathrm{Ti} 30 \mathrm{M} / \mathrm{E} 2$

Figure 6. SEM images of the layers grown in E2 electrolyte after 10, 20 and 30 min treatment period: low magnification (a,c,e); high magnification and EDS analysis points $(\mathbf{b}, \mathbf{d}, \mathbf{f})$; point element mass concentrations (wt. $\%$ ). 


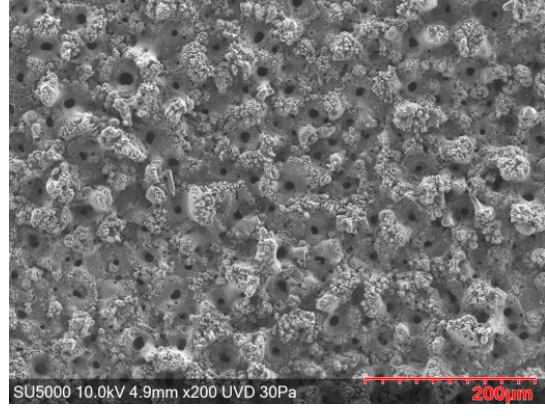

(a) Ti10M/E3

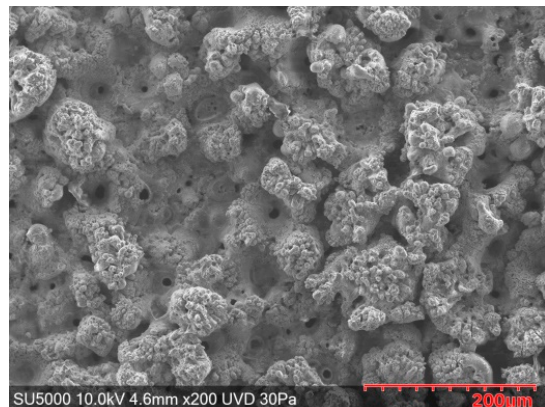

(c) Ti20M/E3

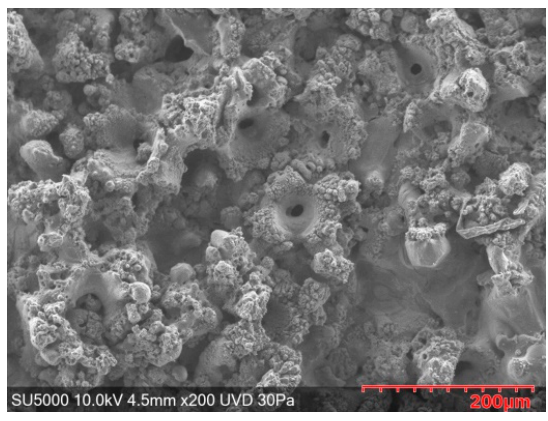

(e) Ti30M/E3
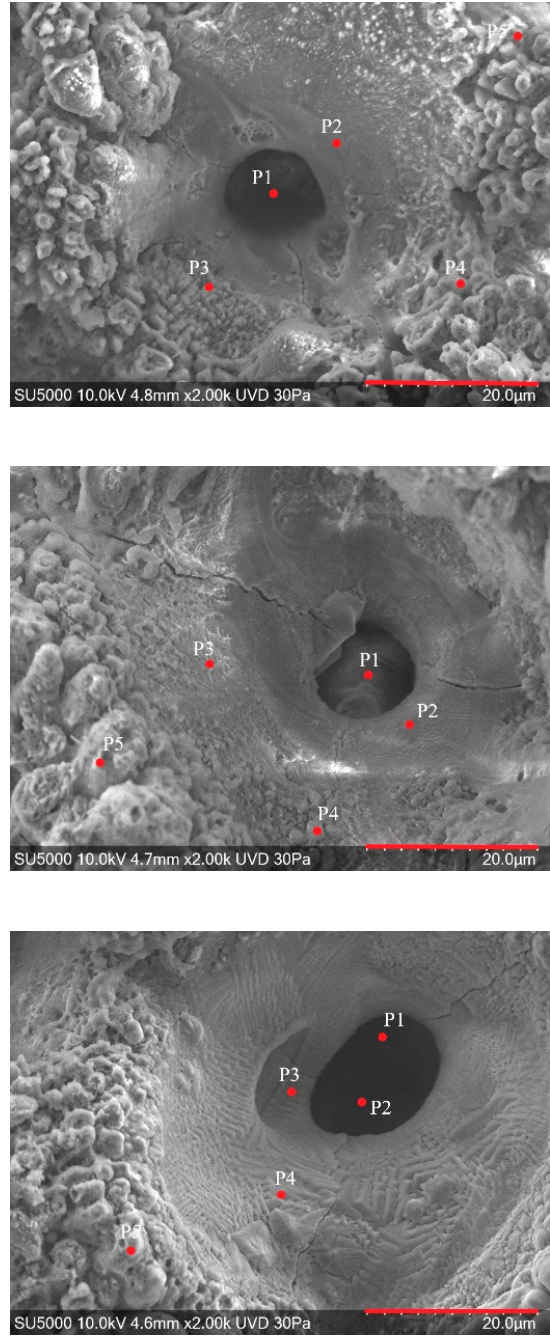

Figure 7. SEM images of the layers grown in E3 electrolyte after 10, 20 and 30 min treatment period: low magnification (a,c,e); high magnification and EDS analysis

points $(\mathbf{b}, \mathbf{d}, \mathbf{f})$; point element mass concentrations (wt.\%).

\begin{tabular}{ccccc}
\hline $\begin{array}{c}\text { Point scan } \\
\text { no. }\end{array}$ & $\begin{array}{c}\mathrm{Ti} \\
\text { (wt.\%) }\end{array}$ & $\begin{array}{c}\mathrm{Al} \\
(\text { wt.\%) }\end{array}$ & $\begin{array}{c}\mathrm{O} \\
\text { (wt.\%) }\end{array}$ & $\begin{array}{c}\mathrm{Na} \\
\text { (wt.\%) }\end{array}$ \\
\hline 1 & 47.4 & 14.5 & 37.6 & 0.5 \\
2 & 27.7 & 21.8 & 49.8 & 0.7 \\
3 & 4.6 & 45.1 & 49.5 & 0.8 \\
4 & 1.3 & 45.6 & 51.6 & 1.6 \\
5 & 17.5 & 42.5 & 39.4 & 0.6
\end{tabular}

(b) Ti10M/E3

\begin{tabular}{ccccc}
\hline $\begin{array}{c}\text { Point scan } \\
\text { no. }\end{array}$ & $\begin{array}{c}\mathrm{Ti} \\
\text { (wt.\%) }\end{array}$ & $\begin{array}{c}\mathrm{Al} \\
\text { (wt.\%) }\end{array}$ & $\begin{array}{c}\mathrm{O} \\
\text { (wt.\%) }\end{array}$ & $\begin{array}{c}\mathrm{Na} \\
\text { (wt.\%) }\end{array}$ \\
\hline 1 & 7.8 & 40.6 & 50.6 & 0.2 \\
2 & 26.1 & 24.6 & 48.6 & 0.7 \\
3 & 6.8 & 40.7 & 52.3 & 0.3 \\
4 & 0.5 & 50.4 & 48.6 & 0.5 \\
5 & 1.2 & 50.1 & 47.8 & 1.0
\end{tabular}

(d) Ti20M/E3

\begin{tabular}{ccccc}
\hline $\begin{array}{c}\text { Point scan } \\
\text { no. }\end{array}$ & $\begin{array}{c}\mathrm{Ti} \\
\text { (wt.\%) }\end{array}$ & $\begin{array}{c}\mathrm{Al} \\
\text { (wt.\%) }\end{array}$ & $\begin{array}{c}\mathrm{O} \\
\text { (wt.\%) }\end{array}$ & $\begin{array}{c}\mathrm{Na} \\
\text { (wt.\%) }\end{array}$ \\
\hline 1 & 7.4 & 41.1 & 50.4 & 1.1 \\
2 & 7.7 & 40.5 & 50.7 & 1.1 \\
3 & 15.2 & 32.5 & 51.5 & 0.8 \\
4 & 12.5 & 35.4 & 52.0 & 0.2 \\
5 & 5.0 & 47.4 & 46.8 & 0.8
\end{tabular}

(f) $\mathrm{Ti} 30 \mathrm{M} / \mathrm{E} 3$ 


\subsection{Cross-Sectional SEM/EDS Analysis of the Layers}

The cross-sectional measurements of the coating thickness showed a strong agreement with the metallographic results given in Figure 4, both indicating a layer thickness increase from the initial $\sim 21 \mu \mathrm{m}$ to $\sim 95 \mu \mathrm{m}$ (Figure 8 ) which is an improvement by a factor of five in the oxide films generated under enhanced oxidation conditions (i.e., increased electrolyte concentration and time periods). As Figure 4 shows, the coatings were rather uniform in terms of thickness and varied up to approximately $10 \mu \mathrm{m}$.
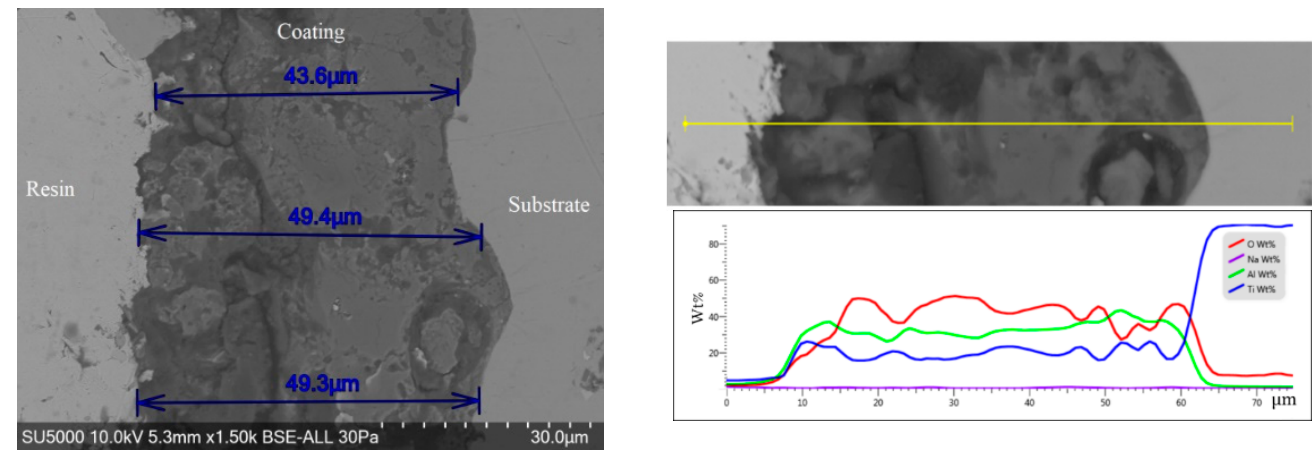

(a)
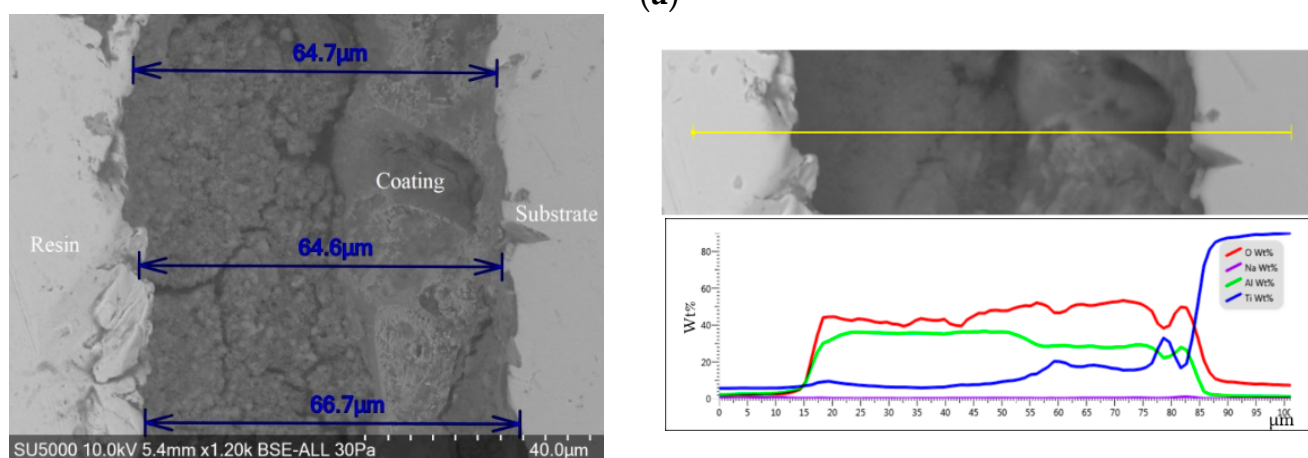

(b)
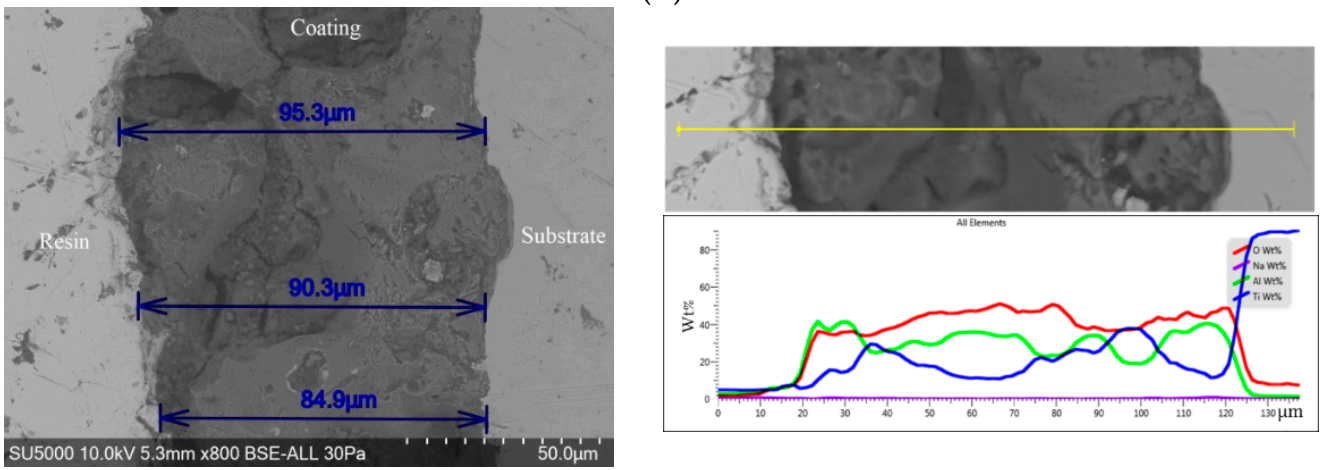

(c)

Figure 8. Cross-sectional images and EDS line profiles of the PEO coatings formed in E3 electrolyte after 10, 20 and 30 min treatment period. (a) Ti10M/E3; (b) Ti20M/E3; (c) Ti30M/E3.

The EDS line profiles illustrated in Figure 8 indicate the distribution of each element across the PEO layer and the metal substrate as well as all the elements of the coating. As the oxidation time increased, the substrate interface varied depending on the layer thickness, which is normal considering the increase of oxygen and aluminum content. This can be interpreted as supplementary evidence for alumina occurrence at the surface and in the bulk, as demonstrated by XPS and XRD results (Figures 1-3). 


\subsection{Microhardness}

For the microhardness measurements of the coatings, three different points were tested for each sample with the resulting mean values given in Table 2. The standard deviation was found to be in the range of $5-10 \%$.

Thus, it is very easy to notice the increasing tendency of hardness with the PEO process duration for every sample set. Additionally, compared to the uncoated substrate, the coatings exhibited hardness values 9 to 28 times higher than those of pure Ti. However, a peculiar behavior of microhardness with decreased values was observed when the electrolyte concentration reached its maximum. As discussed in the previous section, this mechanical response of the PEO surface layers could be attributed to the morphological changes occurring at higher concentration of aluminate and associated with grain-like surface structures (Figure 7). Nevertheless, the current hardness values are much higher than those reported in our previous work [15] in which the PEO coatings were grown without additional $\mathrm{NaOH}$; this can be linked to the higher alumina content and lower aluminum titanate inside the films.

\subsection{Adhesion Strength}

Similar to the microhardness measurements, three values of the critical loads at which detachment of the film from the substrate (Lc2) occurred were recorded, and the average values are reported in Table 2. The standard deviation was estimated at $5-10 \%$.

Regarding the scratch resistance of the studied samples, the coated surfaces exhibited a significant improvement after each growth cycle of the PEO process with respect to the process duration and electrolyte concentration. The critical loads ranged from 11 to $50 \mathrm{~N}$, and the best scratch resistance was found for the thickest coatings at higher oxidation periods and aluminate concentrations, as presented in Table 2. When compared to the samples oxidized in $\mathrm{NaOH}$ conditions [15], the layers in the present study exhibited a better adhesion strength due to the high presence of alumina in the PEO films.

\subsection{Potentiodynamic Polarization Tests}

The corrosion resistance was assessed by means of potentiodynamic polarization measurements with a $3.5 \mathrm{wt} . \%$ sodium chloride solution at room temperature. By comparing the uncoated and coated surfaces of Ti substrate, one can notice decrease of corrosion current densities by two orders of magnitude compared to the bare Ti substrate (Figure 9, Table 3). Additionally, a close inspection of Table 3 reveals the correlations between process time and electrolyte concentration regarding the corrosion behavior of the coatings; hence, the corrosion resistance was enhanced by increasing the PEO duration and $\mathrm{NaAlO}_{2}$ concentration. The best corrosion performance was achieved for the sample treated for $30 \mathrm{~min}$ in E3 electrolyte, which was associated with the thickest PEO film obtained (Figure 4, Table 2). A comparison of the layers prepared with [15] and without $\mathrm{NaOH}$ addition indicates that there was a clear improvement in the corrosion behavior of samples obtained in the absence of $\mathrm{NaOH}$ in the electrolytic solution (Table 3), which can also be correlated with higher $\alpha$ and $\gamma$-alumina and lower aluminum titanate concentrations in the coating layers. 


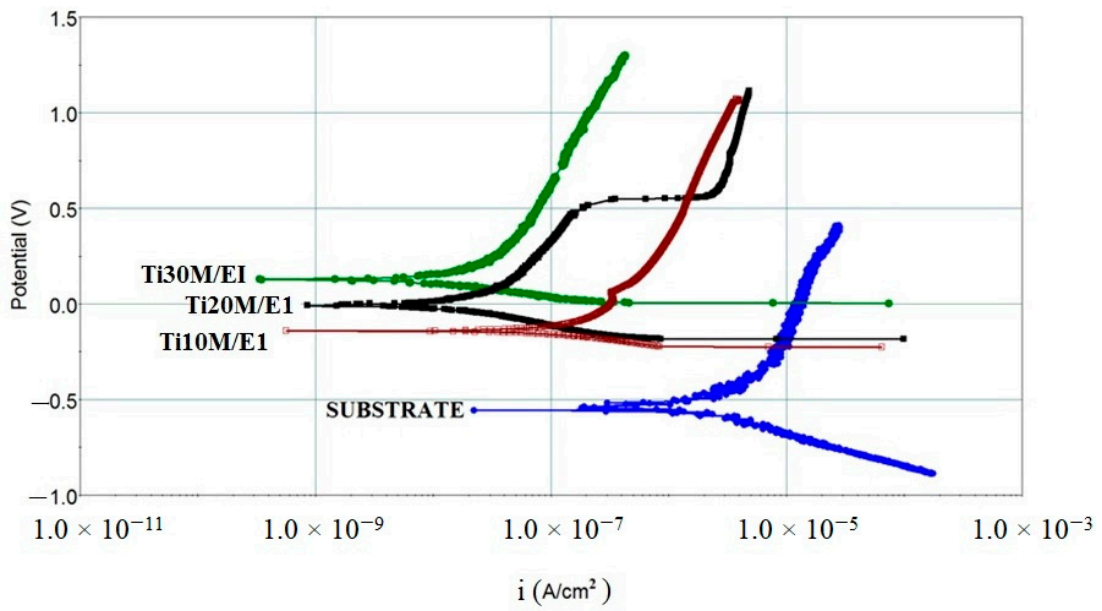

(a)

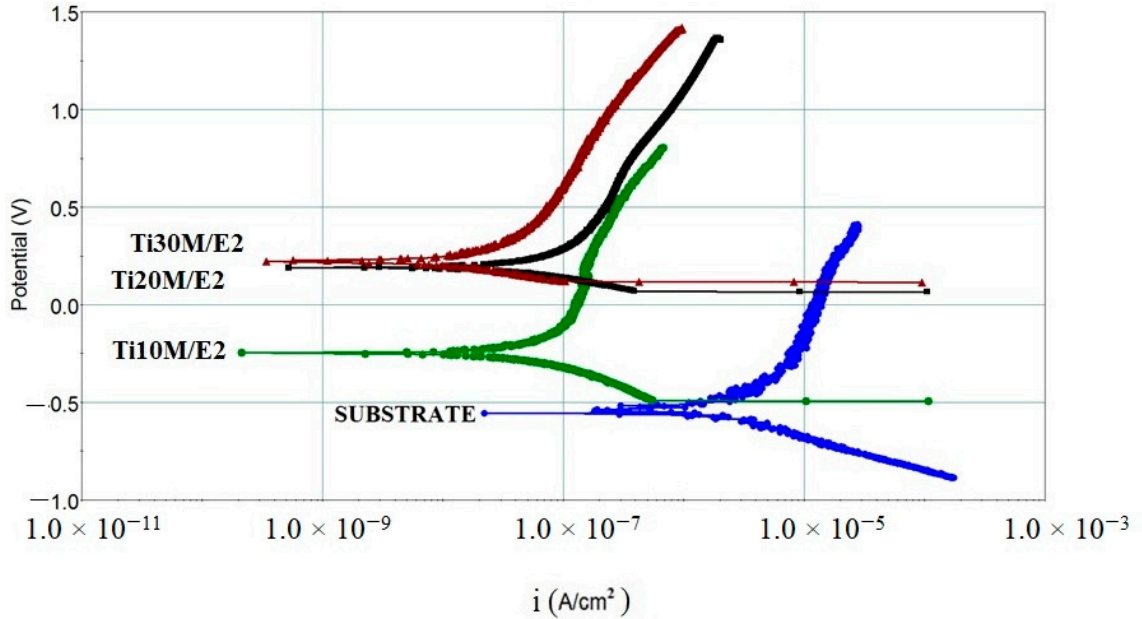

(b)

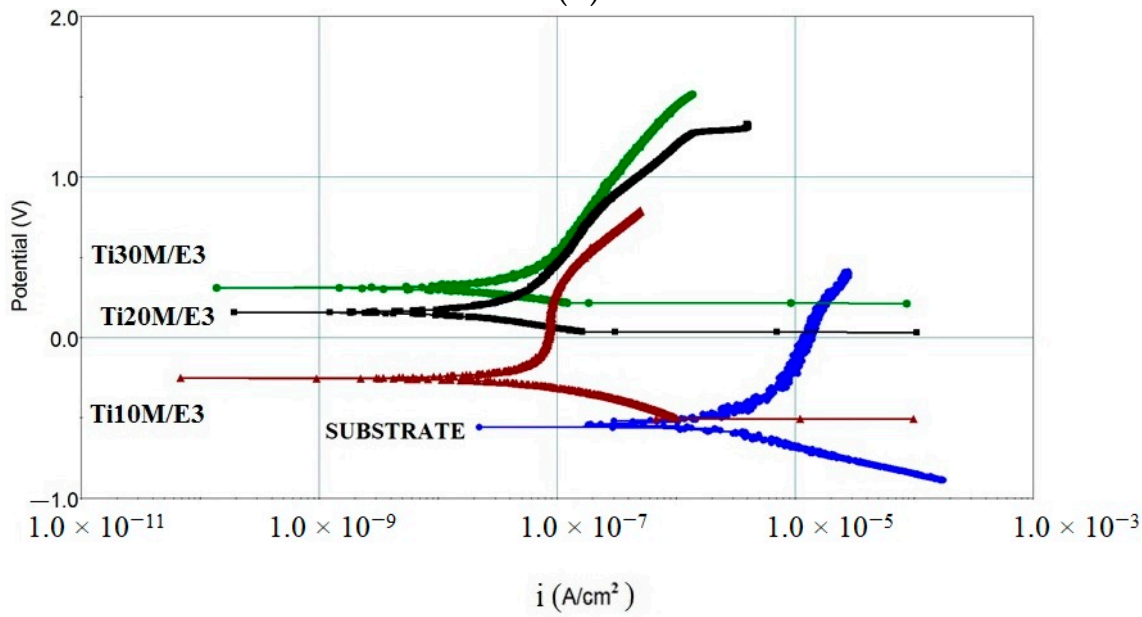

(c)

Figure 9. Potentiodynamic polarization curves of $\mathrm{Cp}$-Ti substrate and PEO coatings formed after 10, 20 and 30 min PEO process time in: (a) E1; (b) E2; (c) E3 electrolyte.

\section{Conclusions}

Grade 2 commercially pure titanium was successfully processed by plasma electrolytic oxidation method using a galvanostatic regime operated at a constant current density of $0.36 \mathrm{~A} / \mathrm{cm}^{2}$ in a $\mathrm{NaAlO}_{2}$ electrolyte solution at concentrations of 10,15 and $20 \mathrm{~g} / \mathrm{L}$ to 
produce coatings with enhanced hardness and corrosion resistance as compared to bare titanium substrate.

The coating layers were mainly composed of aluminum oxide crystallized as $\alpha-\mathrm{Al}_{2} \mathrm{O}_{3}$ and $\gamma-\mathrm{Al}_{2} \mathrm{O}_{3}$, with a minor contribution from $\mathrm{TiAl}_{2} \mathrm{O}_{5}$ and $\mathrm{Na}_{2} \mathrm{Ti}_{4} \mathrm{O}_{9}$ phases. In the outer layers, the temperature increase in the microarc electric discharge region due to the high working voltages applied in the PEO process favored the partial decomposition of the metastable $\mathrm{TiAl}_{2} \mathrm{O}_{5}$ to $\mathrm{TiO}_{2}$ and $\mathrm{Al}_{2} \mathrm{O}_{3}$.

The highest amount of aluminum oxide inside the coatings was higher than $90 \%$ after 30 min PEO treatment.

The obtained layer thicknesses were in the range of 21-95 $\mu \mathrm{m}$ and increased with increasing electrolyte concentration and oxidation time.

The surface morphology of the coatings showed a conglomeration of aluminum oxide as nodules and grains, both of which reduced the pore density when increased aluminate concentration and process duration were applied.

The best scratch resistance was found for the thickest coatings at higher oxidation periods and aluminate concentrations.

All PEO coatings exhibited excellent hardness and corrosion resistance performance, far exceeding the values of pure titanium samples.

Author Contributions: A.H.M.: conceptualization and writing-original draft. V.M.: validation, conceptualization and supervision. M.L. and C.P.L.: data curation, visualization, investigation and supervision. C.D. and S.M.: data curation and investigation. V.A. and E.C.: validation, resources and methodology. V.C.: data curation, visualization and investigation. All authors have read and agreed to the published version of the manuscript.

Funding: M. Lungu received funding from the grant of Executive Agency for Higher Education, Research, Development and Innovation Funding-UEFISCDI (Grant No. PN-III-P1-1.1-PD-2019-0745).

Institutional Review Board Statement: Not applicable.

Informed Consent Statement: Not applicable.

Data Availability Statement: Not applicable.

Conflicts of Interest: The authors declare no conflict of interest. The funders had no role in the design of the study; in the collection, analysis, or interpretation of data; in the writing of the manuscript or in the decision to publish the results.

\section{References}

1. Yang, X.; Liu, C.R. Machining titanium and its alloys. Mach. Sci. Technol. 1999, 3, 107-139. [CrossRef]

2. Poondla, N.; Srivatsan, T.; Patnaik, A.; Petraroli, M. A study of the microstructure and hardness of two titanium alloys: Commercially pure and Ti-6Al-4V. J. Alloys Compd. 2009, 486, 162-167. [CrossRef]

3. Boyer, R.R. Attributes, characteristics, and applications of titanium and its alloys. JOM 2010, 62, 21-24. [CrossRef]

4. Wilson, A.D.; Leyland, A.; Matthews, A. A comparative study of the influence of plasma treatments, PVD coatings and ion implantation on the tribological performance of Ti-6Al-4V. Surf. Coat. Technol. 1999, 114, 70-80. [CrossRef]

5. Proudhon, H.; Savková, J.; Basseville, S.; Guipont, V.; Jeandin, M.; Cailletaud, G. Experimental and numerical wear studies of porous Reactive Plasma Sprayed Ti-6Al-4V/TiN composite coating. Wear 2014, 311, 159-166. [CrossRef]

6. Askari, S.J.; Akhtar, F.; Chen, G.C.; He, Q.; Wang, F.Y.; Meng, X.M.; Lu, F.X. Synthesis and characterization of nano-crystalline CVD diamond film on pure titanium using $\mathrm{Ar} / \mathrm{CH}_{4} / \mathrm{H}_{2}$ gas mixture. Mater. Lett. 2007, 61, 2139-2142. [CrossRef]

7. Selamat, M.S.; Baker, T.; Watson, L. Study of the surface layer formed by the laser processing of Ti-6Al-4V alloy in a dilute nitrogen environment. J. Mater. Process. Technol. 2001, 113, 509-515. [CrossRef]

8. Langlade, C.; Vannes, A.; Krafft, J.; Martin, J. Surface modification and tribological behaviour of titanium and titanium alloys after YAG-laser treatments. Surf. Coat. Technol. 1998, 100, 383-387. [CrossRef]

9. Zhao, Y.; Lu, M.; Fan, Z.; Huang, S.; Huang, H. Laser deposition of wear-resistant titanium oxynitride/titanium composite coatings on Ti-6Al-4V alloy. Appl. Surf. Sci. 2020, 531, 147212. [CrossRef]

10. Zhao, X.; Liu, H.; Li, S.; Wang, X.; Sheng, Y.; Zhang, P.; Li, W. Combined effect of TiN coating and surface texture on corrosion-wear behavior of selective laser melted CP-titanium in simulated body fluid. J. Alloys Compd. 2019, 816, 152667. [CrossRef]

11. Spajić, I.; Rodič, P.; Šekularac, G.; Lekka, M.; Fedrizzi, L.; Milošev, I. The effect of surface preparation on the protective properties of $\mathrm{Al}_{2} \mathrm{O}_{3}$ and $\mathrm{HfO}_{2}$ thin films deposited on cp-titanium by atomic layer deposition. Electrochim. Acta 2020, 366, 137431. [CrossRef] 
12. Molaei, M.; Nouri, M.; Babaei, K.; Fattah-Alhosseini, A. Improving surface features of PEO coatings on titanium and titanium alloys with zirconia particles: A review. Surf. Interfaces 2020, 22, 100888. [CrossRef]

13. Fattah-Alhosseini, A.; Molaei, M.; Nouri, M.; Babaei, K. Review of the role of graphene and its derivatives in enhancing the performance of plasma electrolytic oxidation coatings on titanium and its alloys. Appl. Surf. Sci. Adv. 2021, 6, 100140. [CrossRef]

14. Walsh, F.C.; Low, C.T.J.; Wood, R.; Stevens, K.T.; Archer, J.; Poeton, A.R.; Ryder, A. Plasma electrolytic oxidation (PEO) for production of anodised coatings on lightweight metal (Al, Mg, Ti) alloys. Trans. IMF 2009, 87, 122-135. [CrossRef]

15. Malinovschi, V.; Marin, A.; Ducu, C.; Andrei, V.; Coaca, E.; Craciun, V.; Lungu, M. Influence of sodium aluminate concentration and process duration on microstructure, mechanical and electrochemical behavior of PEO coatings formed on CP-Ti. Surf. Coat. Technol. 2021, 418, 127240. [CrossRef]

16. Aliasghari, S.; Němcová, A.; Čížek, J.; Gholinia, A.; Skeldon, P.; Thompson, G.E. Effects of reagent purity on plasma electrolytic oxidation of titanium in an aluminate-phosphate electrolyte. Trans. Inst. Met. Finish. 2016, 94, 32-42. [CrossRef]

17. Ghafaripoor, M.; Raeissi, K.; Santamaria, M.; Hakimizad, A. The corrosion and tribocorrosion resistance of PEO composite coatings containing $\alpha-\mathrm{Al}_{2} \mathrm{O}_{3}$ particles on $7075 \mathrm{Al}$ alloy. Surf. Coat. Technol. 2018, 349, 470-479. [CrossRef]

18. Tao, Y.; Xiong, T.; Sun, C.; Jin, H.; Du, H.; Li, T. Effect of $\alpha-\mathrm{Al}_{2} \mathrm{O}_{3}$ on the properties of cold sprayed $\mathrm{Al} / \alpha-\mathrm{Al}_{2} \mathrm{O}_{3} \mathrm{composite}$ coatings on AZ91D magnesium alloy. Appl. Surf. Sci. 2009, 256, 261-266. [CrossRef]

19. Zhao, Z.; Chen, M.; You, C.; Li, W.; Tie, D.; Liu, H. Effect of $\alpha-\mathrm{Al}_{2} \mathrm{O}_{3}$ additive on the microstructure and properties of MAO coatings prepared on low carbon steel. J. Mater. Res. Technol. 2020, 9, 3875-3884. [CrossRef]

20. Li, Y.; Chen, M.; Li, W.; Wang, Q.; Wang, Y.; You, C. Preparation, characteristics and corrosion properties of $\alpha-\mathrm{Al}_{2} \mathrm{O}_{3}$ coatings on 10B21 carbon steel by micro-arc oxidation. Surf. Coat. Technol. 2018, 358, 637-645. [CrossRef]

21. Moulder, F.; Stickle, W.F.; Sobol, P.E.; Bomben, K.D. Handbook of X-ray Photoelectron Spectroscopy; ULVAC-PHI Inc.: Chigasaki, Japan, 1995.

22. Naumkin, A.V.; Kraut-Vass, A.; Gaarenstroom, S.W.; Powell, C.J. NIST X-ray Photoelectron Spectroscopy Database, NIST Standard Reference Database 20, Version 4.1, 2012. Available online: https://srdata.nist.gov/xps/ (accessed on 19 November 2021).

23. Krupa, D.; Baszkiewicz, J.; Kozubowski, J.A.; Barcz, A.; Sobczak, J.W.; Biliński, A.; Lewandowska-Szumieł, M.; Rajchel, B. Effect of phosphorus-ion implantation on the corrosion resistance and biocompatibility of titanium. Biomaterials 2002, 23, 3329-3340. [CrossRef]

24. Kong, D.; Wang, Y.; Huang, S.; Von Lim, Y.; Zhang, J.; Sun, L.; Liu, B.; Chen, T.; Valdivia Alvarado, P.; Yang, H.Y. Surface modification of $\mathrm{Na}_{2} \mathrm{Ti}_{3} \mathrm{O}_{7}$ nanofibre arrays using $\mathrm{N}$-doped graphene quantum dots as advanced anodes for sodium-ion batteries with ultra-stable and high-rate capability. J. Mater. Chem. A 2019, 7, 12751-12762. [CrossRef]

25. Takanabe, K.; Khan, A.M.; Tang, Y.; Nguyen, L.; Ziani, A.; Jacobs, B.W.; Elbaz, A.M.; Sarathy, S.M.; Tao, F. Integrated in situ characterization of a molten salt catalyst surface: Evidence of sodium peroxide and hydroxyl radical formation. Angew. Chem. 2017, 129, 10539-10543. [CrossRef]

26. Pawley, G.S. Unit-cell refinement from powder diffraction scans. J. Appl. Crystallogr. 1981, 14, 357-361. [CrossRef]

27. Xue, W.; Deng, Z.; Lai, Y.; Chen, R. Analysis of phase distribution for ceramic coatings formed by microarc oxidation on aluminum alloy. J. Am. Ceram. Soc. 2005, 81, 1365-1368. [CrossRef]

28. Yerokhin, A.; Leyland, A.; Matthews, A. Kinetic aspects of aluminium titanate layer formation on titanium alloys by plasma electrolytic oxidation. Appl. Surf. Sci. 2002, 200, 172-184. [CrossRef] 